\title{
THE EXTENSION OF AMERICAN BANKING IN FOREIGN COUNTRIES
}

\author{
By Samuel McRoberts, \\ Vice-President, The National City Bank of New York.
}

Until recent times foreign affairs have commanded comparatively little public interest in the United States, but with the broader political position of the nation resulting from the Spanish war and the establishment of a more definite and continuous foreign policy, the interest in our international relations has become much intensified. Along with this quickened interest has come a more general study of our commerce abroad. This study is partially inspired by the general interest in our foreign political relations, but more potently stimulated by the realization that we are reaching the point where, as a nation, we have need at home for those materials and food products which have in the past constituted the bulk of our export trade. Although we have had an increased production during the last three years, our export of unmanufactured food products has declined forty-two per cent, and the export of food products partially manufactured has diminished twenty-two per cent. This decrease has been so marked as to strengthen the conviction that the contribution of foodstuffs that the United States is able to make to the outside world is steadily diminishing, both in actual value and in the percentage of our exports which this class of goods represents. Practically all our public lands have passed into private and productive ownership, and the growing need for our agricultural products, at home, has been such that the competition in domestic markets has raised the price until the exporter is unable to meet the competition of foreign producers. Wheat has, for a large part of the time during the last two years, been steadily above parity for the Liverpool market. American beef, at current prices, can compete in London with the products of Australia and Argentina only in a limited section of the trade. Not having tillable public lands in reserve, we can increase our production only by more intensive processes and on a higher basis of cost. As a consequence, we are 
necessarily turning to manufactured products to maintain our balance of trade with other nations.

In the past the people of the United States have concentrated their minds upon domestic problems; enormous resources had to be developed and a new civilization established. By logical sequence it follows that the American is not a cosmopolitan; that he is indifferently qualified to approach business problems with a clear understanding of the world's needs. The growing necessity for a trade abroad in manufactured articles is forcing the American into a comparatively new field, for which he is admirably equipped in all save experience and the institutions constituting the machinery of such commerce. Raw materials and food products-necessities abroadhave easily been marketed, requiring no such equipment or skill as the merchandising of manufactured goods when in competition with foreign tradesmen who long have occupied the field. American merchants and, to some extent, the American public, are beginning to recognize this situation. From an attitude of complaisant superiority they are becoming aroused to an intelligent examination of foreign markets, and to a comprehension of the conditions that must be complied with, and the equipment necessary to successful operation. The essentials for this foreign merchandising, obtainable through individual application, can be readily acquired; the particular customs of a market, the characteristics of the people, and the class and quality of the goods desired. But that part of the equipment for foreign commerce, which provides transportation and financial exchange, is not to be procured by individual efforts. It can be obtained only through the organization of certain specific forces of civilization, such as units of capital, highly specialized knowledge and the authority and co-operation of governments. It is the acquiring of this part of the equipment for foreign commerce that presents the more serious problem.

It has long been a subject for comment that Americans are obviously content to do their international business through the banks of their foreign competitors. That they have done so at any time, contentedly or not, is inconsistent with American characteristics. That they continue to do so, after having amassed an enormous banking capital and a foreign trade of more than $\$ 2,500$,$\infty 00, \infty 00$, calls for some explanation. Whatever the past causes for such inaction may have been, it is no longer to be explained on 
the ground of indifference. The necessity for the establishing of American banks abroad, in the aid of commerce, has been repeatedly and persistently pointed out by American travelers, the consular service, the State Department of our Government and the public press; and of late it has been so insisted upon as to augur an oblique criticism of the initiative and intelligence of American bankers.

American banks in foreign markets would be powerful aids to the upbuilding of our commerce; manifestly and for the subjoined reasons are they indispensable:

First. They would furnish a direct financial exchange.

Second. They would provide a safe and efficient means of obtaining credit-information, independent as to foreign merchants and impartial as to American exporters.

Third. They would correctly present to foreign customers the standing of our own export houses.

Fourth. They would furnish capital or credit at the foreign market.

Fifth. They would bring American financial interests in touch with foreign enterprises, which, if exploited, would create business for the American exporter.

A direct financial exchange is important because it puts the least burden on the business and is most readily understood and relied upon by the merchant. The difficulty in obtaining a direct exchange with another country comes not only from the dearth of American banks abroad, but from the legal restrictions that obtain as to domestic banks. One of the fundamental principles of European banking practices is that a bank is permitted to sell its good name in lieu of money advanced or a credit placed at the disposal of a borrower. An English manufacturer purchasing materials abroad does so through personal representatives or local firms appointed as agents. When a purchase is made, knowing that the goods must be paid for before shipment, he receives from his banker, commensurate with his financial standing, a credit, to the effect that the bank will accept (guarantee payment) sixty- or ninety-day drafts drawn by the foreign agent with shipping documents attached. These shipping documents are so made as to give the holder of the full sets of bills of lading an absolute control of the goods until they reach their destination. The agent, armed with this draft and the shipping documents, is enabled immediately to place himself in funds 
by the negotiation of this instrument; and the purchaser of the drafts is absolutely protected until the bill of exchange is accepted by the English banker, to whom, in consideration of his acceptance, the document must be surrendered. This practice enables the European merchant to finance his purchases in foreign countries at a minimum cost; and it has contributed enormously to the development of foreign trade. This simple and inexpensive means of bridging the seas could be secured to the American merchant in either of two ways; by the establishing of domestic banks with branches abroad, or through the domestic banker's acceptance of the merchants' drafts. If but American banks had branches abroad, the merchant's deposit in the parent bank could readily be made available at any of its foreign branches; or if an American bank, well known abroad, could add its credit to that of the merchant's by guaranteeing his transactions in accordance with established business usage, he could deal direct with all the ports of the world.

But the American banks have no branches abroad, and they are, moreover, restricted by law from making time acceptances or otherwise guaranteeing commercial paper ; and in consequence the American merchant is forced to employ the services of European banks to finance his transactions. This facility, of course, must needs be well paid for, as the good name of the European banker is not sold cheaply. As a result, the American importer must establish his credit with strangers or suffer the inconvenience, delay and expense of an indirect exchange. A like disadvantage confronts the exporter, for the identical conditions that forced payment in European drafts made those same European drafts the most available exchange for the purpose of collection. Thus the European banker takes toll of our commerce, be it export or import. In addition to the immediate handicap, resulting from indirect exchange, the American suffers collateral disadvantages. For instance, the quotations of the markets of the world are expressed in the nomenclature of Europe-marks, francs or pounds sterling-seldom if ever in American dollars; therefore the American, in naming his price, unavoidably directs the mind of his customer to the European competitor. Furthermore, American prestige suffers seriously from these indirect financial transactions. America conducting her foreign trade through the banks of her neighbors is in about as commanding a position as is a 
bank in a large city that is not a member of the Clearing House Association.

Apart from the question of exchange, the American merchant, in extending his trade, suffers from the lack of intimate contact and confidential relations with the business life of other countries, which can best be supplied by resident American bankers. Under the present state of affairs, if he would inform himself as to particular trade conditions, as to the standing of a customer or make any of the confidential inquiries that are incident to business, he must seek some other firm that is engaged in the same territory in which he is operating, or a banker having much closer affiliations with his competitors in Europe. There has been an effort made to supply this deficiency through the mercantile agencies, but the people of South America and the Orient do not take kindly to the interrogation of such agents; and the information, which otherwise would be readily obtainable by a banking institution, is often withheld and the inquiry resented. American banks abroad would be dependent for their prosperity very largely upon the extent of American commerce in their territory, and, by reason of self-interest, would be the most potent promoters of American enterprise, just as experience has proven the European international bank to be a vitalizing element in the all-nations trade of Europe. Excepting the United States, every important country that is engaged in the exporting of manufactured products, has furnished the facilities under notice for trade through the extension of its banking system to foreign territory. The customs of banking and the laws of the various European commonwealths are not unfavorable to the upbuilding of international banks, consequently the European banking house may set up its branches to the ends of the earth. English banks are as universal as commerce, while those of Germany, France and Italy are co-extensive with German, French and Italian trade. For illustration, take a certain English international bank as being typical under the British system. This is a bank incident to the English interests in South America. Its home office is in London and, as an institution, it is a citizen of England and under the protection of that government's foreign policy. It has branches in Valparaiso, Santiago, Iquique, Antofogasta, Copiapó, Coquimbo, La Serena, Chillan, Concepcion, Punta Arenas and Ovalle, Chili ; Buenos Aires, Mendoza, Bahia Blanca and Rio Gallegas in the Argentine Republic;

(506) 
Montevideo, Uruguay and Oruro, Bolivia, and additionally some forty-five agencies in other parts of South America. The ease, facility and safety for financial transactions, afforded to the Englishman and his interests in that part of the world covered by this institution, can be appreciated at a glance. The banking systems under which these banks are operated make it possible for them to utilize the credit and funds of the entire institution where and as needed, and, by means of the power of acceptances, to furnish the most stable and least expensive way for the transference of credits.

Unfortunately, no such freedom has been granted the banking capital of America. The United States has only one international bank, operating chiefly in the Far East. This unique position of a nation attempting to build a foreign commerce without the equipment of foreign banks is due to the restrictions of the American banking laws,-restrictions that in effect prohibit the setting up of such institutions. The National Bank Act was enacted at a time when little thought was given to foreign commerce. It was drawn solely with an eye on the internal needs; and a study of its text leads one to the conclusion that its author not only failed to make any provision for foreign banking, but, unwittingly, prohibited it by the terms of the act.

Under existing conditions it is possible to establish a bank in the United States in one of three ways: under the National Bank Act, as a national bank; under state law as a state bank, or by means of a co-partnership as a private bank.

Section 5 I90 of the United States Revised Statutes-part of the National Bank Act-sets forth the following edict:

The usual business of each national banking association shall be transacted at the office or banking house located in the place specified in its organization certificate.

This section has been interpreted by every Comptroller of the Currency as prohibiting a national bank from establishing branches. The only exception to this prohibition has come by the conversion of state banks into national institutions under the authority of section 5 I 55 of the Act, which declares:

It shall be lawful for any bank or banking organization organized under State laws and having branches, the capital being joint and assigned to and

(507) 
used by the mother bank and branches in definite proportion, to become a national banking association in conformity with existing laws, and to maintain in operation its branches, or such one or more of them as it may elect to retain, the amount of the circulation redeemable at the mother bank and each branch to be regulated by the amount of capital assigned to and used by each.

Under this section, only, the following named banks have been converted from state into national banks, retaining their branches under the provision of this section:

First National Bank, Milton, Ore. ; branch located at Freewater, Ore.; converted July 23, Igo8.-Bank of California (National Association), San Francisco, Cal. ; branches at Virginia City, Nev., Portland, Ore., Seattle and Tacoma, Wash.; converted February 5 . I9I0.-Pascagoula National Bank, Moss Point, Miss.; branch at Scranton, Miss.; converted March 14, 1907.-First National Bank, Pontotoc, Miss.; a branch at Ecru in same state; converted February $21,1908$.

State banks, under the laws of but few states, are allowed to have branches outside of their immediate states and possibly abroad; but, if it were permissible to convert them into national banks, their branches would have to be designated before such conversion could be effected, thus making the organization inflexible as to its subsequent growth, either as to the number of branches or the amount of capital available for their separate use. It is true of the greater majority of the states that a bank, organized under state law, is restricted to one place of business, or, at least, to branches in the city specified by its charter as the place where its business is to be conducted. Mostly all of the states prohibit any foreign corporation, other than a national bank, from receiving deposits, discounting notes, or carrying on the usual transactions of banking within the borders of the state. The International Banking Corporation, chartered under a special act of the legislature of the State of Connecticut, has an organization with branches in England, China, the Philippine Islands and Panama, with its principal executive office in New York. But, withal, it can do no banking business in New York, and, perforce, is obliged to carry on its transactions in this country through an agency, on exactly the same basis as banks of foreign countries, a hindrance technically valid under the law, but, in equity, a poor recognition of the patriotic spirit and intelligent enterprise that prompted the founding of that institution. 
Private or co-partnership banks are necessarily too restricted as to capital and resources and too unstable in their organization to command the credit and prestige necessary to foreign operation. Foreign corporations are excluded from the banking field here and in many of the foreign countries as well.

From the foregoing it is plainly evident that, under the prevailing status of the law, it is impossible to establish a bank with American citizenship that could conduct a banking business at any important point in the United States and, cotemporaneously, do a primary business abroad.

If there is to be a normal growth in the foreign commerce of the United States there must be an extension of our banking system, adequate to meet the conditions imposed upon the American merchant in his competition with the rest of the world. Obviously the first step toward securing such an extension would be to expand the scope of our banking laws, so as to give some legal basis for the international business. This might be accomplished by permitting the establishment of a new class of banks,-these banks to be under the authority and supervision of the Federal Government to the same extent as are now the national banks,-giving them all the powers vested in national banks, with the added privilege of establishing branches abroad, together with the liberty of making time acceptances of foreign drafts or other forms of commercial exchange originating abroad. Due caution could be observed by putting a logical limitation upon the power of such banks to lend their credit; moreover, by restricting the amount of outstanding guarantees to a definite proportion of their resources,-just as custom and the settled opinion as to sound banking now limit such operations on the part of European banks. The same result could well be achieved by extending these privileges-subject to regulation-to all national banks of sufficient capital, upon the approval of the Secretary of the Treasury and the Comptroller of the Currency. Either course would open the way for the international bank, with its headquarters at one of the centers of trade in this country and its branches covering a definite field of commerce abroad and with strength of capital that would give prestige and stability to its most inferior branches; or, to the same end, invest a national bank with the power to establish isolated branches where the needs of its patrons would make profitable such extensions. Thus situated, such banks would be enti- 
tled to the full protection of the Federal Government in the proper exercise of their functions abroad; but, if subject to the supervision and regulation of federal officers, they would be powerless to embarass our government in its foreign relations. And no good reason presents itself why such banks could not be given efficient federal supervision. Examinations of foreign branches, co-ordinately with the parent bank, could be made by consuls or other resident government agents, appointed as deputy examiners for such a purpose. The four national banks, previously mentioned, have been regularly examined since their conversion from state banks, and, too, without administrative difficulties. Substantial precedents have already been created for the federal supervision of banks in a noncontiguous territory. There are four national banks in Hawaii, one in Porto Rico and two in Alaska. These banks are regularly examined and reported upon by deputy examiners resident at the several localities mentioned.

In brief, this extension could be brought about by amendments to the National Bank Act that would affect neither the present status of our domestic banks, nor would it incur the dangers and disadvantages that have been so unremittingly urged by the opponents of a revised banking system. Such a modification of our banking laws would disturb no vested interests and wotld confer no special privilege. Instead, it would open the foreign field equally to all sections of the country and secure to our foreign trade a normal development along the lines of the least resistance. This country, to-day, is employing a banking capital of $\$ 3,700,000,000$, represented by the capital and surplus of its banking institutions; and when we compare this with the $\mathfrak{E} 8,000,000$ of English banking capital, it can hardly be questioned that we are fortified abundantly to finance our own foreign commerce, and that the opportunity for so doing would straightway be turned to profitable account. Such a move would be timely from the standpoint of our present necessities, and would be a most important and logical step toward enabling the United States eventually to become a creditor nation. 